\title{
DAMPAK COVID 19 TERHADAP TARGET DAN REALISASI PENERIMAAN PAJAK HOTEL DAN RESTORAN DI KOTA MAKASSAR
}

\author{
Syamsuddin \\ ${ }^{1}$ Jurusan Administrasi Niaga, Politeknik Negeri Ujung Pandang \\ Syamsuddin@poliupg.ac.id.
}

\begin{abstract}
ABSTRAK
Penelitian ini dilatar belakangi oleh kehadiran covid 19 yang menyebabkan terjadi penurunan aktivitas ekonomi yang diduga dapat berdampak negatif terhadap pajak hotel dan restoran di Kota Makassar. Penelitian ini bertujuan untuk mengetahui dampak covid 19 terhadap target dan realisasi penerimaan pajak hotel dan restoran di Kota Makassar.

Metode pengumpulan data adalah dokumentasi, studi pustaka dan pengamatan langsung. Metode analisis adalah analisis deskriptif kuantitatif dan kualitatif. Hasil penelitian ini menunjukkan bahwa covid 19 berdampak negatif terhadap target dan realisasi penerimaan pajak hotel dan restoran di Kota Makassar.
\end{abstract}

Kata kunci: Covid 19, pajak hotel dan restoran

\section{ABSTRACT}

This research is motivated by the presence of Covid 19 which causes a decrease in economic activity which is thought to have a negative impact on hotel and restaurant tax revenues in Makassar City. This study aims to determine the impact of covid 19 on the target and realization of hotel and restaurant tax in Makassar City.

Data collection methods are documentation, literature review and observation. The analysis method is quantitative and qualitative descriptive analysis. The results of this study that Covid 19 has a negative impact on the target and realization of hotel and restaurant tax revenues in Makassar City.

Keywords: Covid 19, hotel and restaurant tax

\section{PENDAHULUAN}

Kota Makassar adalah merupakan pintu gerbang Kawasan Timur Indonesia yang memiliki posisi yang sangat strategis. Memperhatikan fenomena di lapangan menunjukkan bahwa terjadi pertumbuhan penduduk dan aktivitas perekonomian yang sangat tinggi. Menurut Tribun Timur (Senin, 26 September 2011) bahwa jumlah penduduk Kota Makassar yang cenderung meningkat dari tahun ke tahun dan pertumbuhannya sangat tinggi yakni pada tahun 2010 sebanyak 1,2 juta dan pada tahun 2011 mencapai 1,5 juta jiwa, karena Makassar sebagai "Ruang Tamu" Kawasan Timur Indonesia (KTI), ramai dikunjungi dan menjadi alternatif untuk mencari penghidupan. Sementara dari sisi pertumbuhan ekonomi, sejak 2006 mencapai di atas enam persen atau lebih tinggi dari persentase pertumbuhan ekonomi nasional. Bahkan angka pertumbuhan ekonomi Makassar sempat menembus 10,51 persen. Itu terjadi ketika pembangunan Bandara Internasional Sultan Hasanuddin, jalan tol dan mega proyek Trans Studio.

Kota Makassar yang memiliki banyak sumber-sumber pajak hotel dan restoran tentunya diharapkan penerimaan pajak hotel dan restoran dikelola dengan baik dalam rangka meningkatkan pembangunan di Kota Makassar. Pengelolaan itu baik jika aturan, kebijakan, perencanaan dan 
pelaksanaannya baik. Dalam UU No. 28 tahun 2009, terdapat 11 jenis pajak, 2 diantaranya adalah pajak hotel dan pajak restoran.

Perencanaan target pajak diperlukan sebagai tolak ukur target yang diharapkan dapat dicapai. Realisasi penerimaan pajak perlu dibandingkan dengan target pajak. Untuk itu perlu diketahui tingkat efektivitas penerimaan pajak hotel dan restoran.

Kehadiran virus corona atau coronavirus disease 2019 (covid-19) telah membuat situasi ekonomi di seluruh dunia memburuk. Bahkan, lembaga keuangan dunia seperti International Monetary Fund (IMF) telah memproyeksikan bahwa ekonomi global tumbuh minus di angka 3\%. Lalu, bagaimana dengan Indonesia? Seberapa besar pengaruh covid-19 terhadap perekonomian Indonesia?

Pemerintah, melalui Kementerian Keuangan telah mencatat setidaknya ada delapan dampak utama merebaknya covid-19 bagi perekonomian Indonesia, mulai dari Tenaga kerja hingga kinerja industri di Tanah Air. Dampak ini secara masif telah meluluh lantahkan sendi-sendi sosial dan perekonomian Indonesia.Covid-19 terjadi pada awal tahun 2020 yang menyebabkan terjadinya pembatasan sosial (social distancing), pembatasan jarak fisik (phisical distancing) bahkan pembatasan sosial berskala besar (PSBB) di Kota Makassar. Pembatasan tersebut mulai terjadi secara bertahap pada bulan Maret 2020 dan berlangsung sampai sekarang. Pembatasan tersebut menyebabkan terjadinya penurunan aktivitas ekonomi yang tentunya perlu diketahui dampak (pengaruhnya) terhadap target dan realisasi penerimaan pajak hotel dan restoran.

Tujuan penelitian ini adalah untuk mengetahui dampak covid-19 terhadap target dan realisasi penerimaan pajak hotel dan restoran di Kota Makassar.

\section{TINJAUAN PUSTAKA}

Pajak daerah diatur dalam UU RI Nomor 28 Tahun 2009 Tentang Pajak Daerah dan Retribusi Daerah. Selanjutnya pajak daerah Kota Makassar diatur dalam Peraturan Daerah Kota Makassar Nomor 2 Tahun 2018. Menurut UU RI Nomor 28 Tahun 2009 dan Peraturan Daerah Kota Makassar Nomor 2 Tahun 2018 bahwa jenis pajak daerah Kabupaten/Kota terdiri dari:

1. Pajak Hotel;

2. Pajak Restoran;

3. Pajak Hiburan

4. Pajak Reklame

5. Pajak Penerangan Jalan;

6. Pajak Mineral Bukan Logam dan Batuan;

7. Pajak Parkir;

8. Pajak Air Tanah

9. Pajak Sarang Burung Walet

10. Pajak Bumi dan Bangunan Pedesaan dan Perkotaan

11. Bea Perolehan Hak atas Tanah dan Bangunan.

Adapun pengertian hotel dan pajak restoran Menurut UU RI Nomor 28 Tahun 2009 dan

Peraturan Daerah Kota Makassar Nomor 2 Tahun 2018 sebagai berikut:

1. Pajak Hotel adalah pajak atas pelayanan yang disediakan oleh Hotel;

2. Hotel adalah fasilitas penyedia jasa penginapan/peristirahatan termasuk jasa terkait lainnya dengan dipungut bayaran, yang mencakup juga motel, gubuk pariwisata, wisma pariwisata, pesanggarahan, rumah penginapan dan sejenis;

3. Pajak Restoran adalah Pajak atas pelayanan yang disediakan oleh restoran; 
4. Restoran adalah fasilitas penyedia makanan dan/atau minuman dengan dipungut bayaran, yang mencakup juga rumah makan, kafetaria, kantin, warung, bar, dan sejenisnya termasuk jasa boga/katering;

Menurut UU RI Nomor 28 Tahun 2009, Tarif Pajak Hotel ditetapkan paling tinggi sebesar $10 \%$ (sepuluh persen) dari jumlah pembayaran atau yang seharusnya dibayar kepada Hotel. Tarif Pajak restoran ditetapkan paling tinggi sebesar 10\% (sepuluh persen) dari jumlah pembayaran atau yang seharusnya dibayar kepada restoran. Tarif Pajak hotel dan pajak restoran ditetapkan dengan Peraturan Daerah. Selanjutnya dalam Peraturan Daerah Kota Makassar Nomor 2 Tahun 2018 dinyatakan bahwa Tarif Pajak hotel ditetapkan sebesar 10\% (sepuluh persen) dan Tarif Pajak restoran ditetapkan sebesar 10\% (sepuluh persen).

Menurut Hanoatubun, S. (2020), Susilawati, Falefi dan Purwoko (2020) dan Santoso, Y. I. (2020). dampak covid-19 terhadap perekonomian Indonesia adalah:

1. Terjadinya PHK. Untuk pekerja yang dirumahkan dan kena PHK, lebih dari 1,5 juta,". Dari jumlah ini, 90 persen dirumahkan dan 10 persen kena-PHK. Sebanyak 1,24 juta orang adalah pekerja formal dan265 ribu pekerja informal

2. Kontraksi PMI Manufacturing. PMI Manufacturing umumnya menunjukkan kinerja industri pengolahan dalam negeri, baik dari sisi produksi, permintaan baru hingga ketenagakerjaan yang sangat besar sehingga membawa dampak yang sangat berat utamanya bagi para buruh. Kementerian keuangan mencatat, PMI Manufacturing Indonesia mengalami kontraksi yang cukup dalam hingga 45,3 atau lebih rendah dibandingkan angka per Agustus 2019 yang masih berada di angka 49.

3. Kinerja Impor. Kinerja Impor juga mengalami penurunan yang sangat drastis, pada triwulan I 2020 turun 3,7 persen year-to-date (ytd).

4. Dampak Inflasi. Kementerian Keuangan mencatat, bahwa Inflasi dalam negeri per Maret 2020 mencapai 2,96 persen year-on-year (yoy). Inflasi ini disumbangkan oleh harga emas perhiasan dan beberapa komoditas pangan.

5. Terdapat 12.703 penerbangan di 15 bandara dibatalkan sepanjang Januari-Maret 2020. Rinciannya yaitu 11.680 untuk penerbangan domestik dan 1.023 untuk penerbangan internasional.

6. Kunjungan turis turun hingga 6.800 per hari, khususnya turis dari Cina.

7. Angka kehilangan pendapatan di sektor layanan udara mencapai Rp 207 miliar. Sekitar Rp 4,8 diantaranya disumbang dari penerbangan dari dan ke Cina.

Penurunan okupansi/penempatan pada 6 ribu hotel turun hingga 50 persen.

Selain itu, Direktur Jenderal Pajak Suryo Utomo membeberkan tiga dampak pandemi virus corona terhadap ekonomi (CNN Indonesia, 14 Juli 2020) yakni:

1. Konsumsi rumah tangga atau daya beli yang merupakan penopang 60 persen terhadap ekonomi jatuh cukup dalam. Hal ini dibuktikan oleh data dari BPS yang mencatat konsumsi rumah tangga turun dari 5,02 persen pada kuartal I 2019 ke 2,84 persen pada kuartal I tahun ini.

2. Pandemi menimbulkan ketidakpastian yang berkepanjangan sehingga investasi ikut melemah dan berimplikasi pada terhentinya usaha.

3. Seluruh dunia mengalami pelemahan ekonomi sehingga menyebabkan harga komoditas turun dan ekspor Indonesia ke beberapa negara juga terhenti. Turunnya perekonomian berimplikasi pada penerimaan pajak yang hingga semester I 2020 hanya mencapai Rp513,65 triliun atau 44,02 persen dari target berdasarkan Perpres 72 Tahun 2020 
Rp1.198,8 triliun. Angka tersebut terkontraksi 12,01 persen dibanding periode sama tahun lalu (yoy) yaitu Rp 604,3 triliun.

Menurut Direktur Jenderal Pajak Kristiadi, B. B. (2020), akibat covid-19 ada 9 prediksi terkait masa depan perpajakan:

1. Dari defisit menuju konsolidasi fiskal. Dalam rangka menghadapi krisis, pada jangka pendek akan terdapat kebijakan fiskal yang ekspansif yang berakibat bagi defisit anggaran. Sebagai ilustrasi, pasca krisis 2008 rata-rata defisit anggaran negara anggota OECD meningkat 7\%, sedangkan di Uni Eropa bertambah 5\% (2009). Namun, seiring berjalannya waktu program konsolidasi fiskal diterapkan. Hal ini akan ditandai dengan pengelolaan belanja dan optimalisasi penerimaan pajak, baik pusat maupun daerah.

2. Postur penerimaan dan kebijakan pajak. Saat krisis 2008, PPN dan PPh karyawan menjadi sumber penerimaan pajak yang relatif stabil di banyak negara (Brondolo, 2009). Sementara itu, PPh badan yang notabene lebih sensitif terhadap goncangan ekonomi, umumnya merosot drastis. Tidak mengherankan jika kebijakan pasca krisis 2008 banyak berkaitan dengan sektor PPN, entah itu peningkatan tarif, perluasan basis, ataupun pembenahan sistem teknologi informasi (TI) untuk menjamin kepatuhannya (LeBlanc et.al., 2013). Ke depan, pola yang sama kemungkinan besar terjadi. Dibandingkan dengan jenis pajak lainnya, PPN relatif lebih tahan goncangan. Syaratnya ada dua. Selama supply shock tidak akan mendistorsi tingkat kenaikan harga secara umum dan daya beli masyarakat tidak terganggu. Sayangnya, bayang-bayang gelombang PHK bisa berdampak signifikan baik atas PPN maupun PPh orang pribadi. Terlepas dari ancaman tersebut, pembaharuan kebijakan PPN sepertinya akan jadi agenda penting pasca terjadinya pandemi.

3. Upaya mengoreksi penyebab krisis. Pasca krisis, pemerintah umumnya akan mencari penyebab dan mengantisipasi faktor yang sekiranya dapat memicu risiko yang sama di kemudian hari. Tengok saja agenda kebijakan pajak di sektor keuangan setelah 2008. Financial transaction tax, bank levy, hingga skema interest limitation rule jadi sorotan (Weber dan Marres, 2012). Dari sudut pandang yang sama, koreksi semacam ini sepertinya akan berulang. Bukan tidak mungkin jika isu mengenai pajak lingkungan, instrumen fiskal dalam rangka pengendalian eksternalitas, serta redesain kebijakan untuk sektor kesehatan akan jadi agenda di masa mendatang.

4. Volatilitas regulasi dan reformasi pajak. Tekanan untuk menanggulangi defisit dan utang, serta upaya menjaga kestabilan ekonomi akan mendorong berbagai perubahan regulasi pajak. Urgensi melakukan reformasi, baik yang sifatnya komprehensif maupun piecemeal, akan meningkat tajam. Ketidakpastian akibat berbagai perubahan sepertinya bakal menjadi 'normal baru'. Sama seperti krisis keuangan 2008, pandemi covid-19 juga kelihatannya akan membuat suara kelompok masyarakat semakin diperhitungkan. Akibatnya, tuntutan para pemangku kepentingan untuk berpartisipasi dalam agenda reformasi pajak akan semakin banyak (Lang, 2016). Walau lebih menjamin akseptabilitas, reformasi pajak yang berupaya mengakomodasi berbagai kepentingan bisa menghasilkan sistem pajak yang lebih kompleks.

5. Kompetisi pajak. Krisis keuangan global 2008 maupun covid-19 pada intinya sama-sama berakibat buruk bagi perekonomian. Peran aktif sektor swasta dan aliran modal ke dalam negeri menjastifikasi kebutuhan mendorong daya saing (competitiveness) di tingkat global, termasuk melalui instrumen pajak (OECD, 2018). Perubahan sistem pajak, gelontoran insentif, penurunan tarif baik $\mathrm{PPh}$ badan serta tarif pajak atas kapital tetap jadi favorit dan terus meningkat. Insentif pajak litbang dan untuk tujuan penyerapan tenaga kerja diprediksi akan menjadi menu andalan banyak negara. Khusus atas situasi pasca covid-19, kompetisi 
pajak juga turut melibatkan jargon kedaulatan fiskal. Di masa mendatang, kebijakan pajak yang melindungi kepentingan nasional dan bersifat unilateral bakal tak terbendung.

6. Trend global tax governance. Krisis 2008 telah mendorong terwujudnya tata kelola pajak yang semakin baik di tingkat global (Dietsch dan Rixen, 2016). Program transparansi lewat pertukaran informasi dan kerjasama melawan penghindaran pajak melalui base erosion and profit shifting (BEPS) menjadi tonggak penting agenda pajak global. Kedua program tersebut didukung pula oleh empat organisasi internasional - OECD, UN, IMF, dan World Bank dalam platform for collaboration on tax. Pada masa yang akan datang, sentimen secara global akan memasuki fase baru yang mengarah kepada distribusi pajak yang lebih adil. Embrio dari filosofi tersebut pada hakikatnya telah tampak dari pilar 1 dan pilar 2 proposal pajak digital. Prediksi penting lainnya, dominasi OECD lambat laun berkurang dan bergeser kepada G20 dan emerging economies lainnya (Brauner dan Pistone, 2015).

7. Terobosan. Sama halnya dengan krisis 2008, setelah pandemi covid-19 ini usai, akan banyak diskusi menyoal terobosan dalam menambal penerimaan. Mau tidak mau perdebatan tersebut juga turut mempertanyakan mengenai siapa pihak yang selama ini belum patuh dan belum cukup berpartisipasi dalam pembayaran pajak. Sepuluh tahun yang lalu jawabannya ialah perusahaan multinasional. Ke depan, jawabannya bisa jadi high net worth individual (HNWI). Isu ketimpangan akan jadi pemicunya (Vanistendael,2020). Pengalaman dari krisis sebelumnya menunjukkan dampak bagi ketimpangan, baik penghasilan dan aset, kian melebar. Penyesuaian threshold bagi kelompok berpenghasilan rendah, tarif progresif $\mathrm{PPh}$ orang pribadi, maupun pajak yang berbasis atas kekayaan akan semakin dipertimbangkan. Isu mengenai daftar dan pajak atas kekayaan global yang diperjuangkan oleh lembaga swadaya masyarakat (LSM) juga layak dicermati.

8. Strategi otoritas pajak untuk meningkatkan kepatuhan. Pandemi covid-19 memberikan pelajaran penting bagi seluruh otoritas pajak yaitu kesiapan administrasi pajak berbasis teknologi informasi (TI). Ke depan, penggunaan TI akan dikembangkan tidak hanya atas pelayanan dan pelaporan, tapi juga meluas ke arah e-audit, e-access, dan penggunaan artificial intelligence. Prinsip administrasi pajak berbasis transparansi, efisiensi, dan realtime akan didukung sepenuhnya oleh TI. Selain itu, trend penguatan otoritas pajak, perubahan proses bisnis dari kemampuan mengakses ke kemampuan mengolah informasi, serta perluasan paradigma cooperative compliance (Darussalam, et al., 2018) diperkirakan akan meningkat. Semuanya itu demi optimalisasi kepatuhan pajak.

9. Sengketa dan wajib pajak. Perubahan regulasi dan tingginya kebutuhan penerimaan diperkirakan akan meningkatkan jumlah sengketa. Prediksi ini hakikatnya mengulang pola yang terjadi pasca krisis 2008. Bagi wajib pajak, kondisi ini akan menciptakan kebutuhan untuk tax assurance, pengelolaan risiko pajak (tax risk management) yang lebih baik, serta penerapan tax control framework dalam perusahaan (Russo, 2015).

\section{METODE PENELITIAN}

Penelitian ini dilaksanakan pada Badan Pendapatan Daerah (BAPENDA) Kota Makassar. Waktu penelitian ini dilaksanakan pada bulan Juni-Juli 2020.

Data yang digunakan dalam penelitian ini terdiri dari data primer dan sekunder. Data primer adalah data yang diambil langsung oleh peneliti di lapangan berupa data hasil wawancara dan pengamatan. Sedangkan data sekunder adalah data yang diperoleh dari dokumen yang berisi target dan penerimaan pajak hotel dan restoran di Kota Makassar 
Teknik yang digunakan dalam penelitian ini adalah dokumentasi yaitu mengumpulkan data pajak hotel dan restoran Kota Makassar tahun 2019 dan 2020 di BAPENDA Kota Makassar, wawancara yaitu melakukan wawancara kepada pengelola hotel dan restoran dan pengamatan yaitu melakukan pengamatan terhadap kondisi eksisting di lapangan. Pengolahan data dilakukan dengan membandingkan target dan realisasi penerimaan pajak tahun 2019 dengan 2020.

Definisi operasional beberapa variabel penelitian sebagai yang perlu diperjelas adalah:

1. Pajak Hotel adalah pajak atas pelayanan yang disediakan oleh fasilitas penyedia jasa penginapan/peristirahatan termasuk jasa terkait lainnya dengan dipungut bayaran, yang mencakup juga motel, gubuk pariwisata, wisma pariwisata, pesanggarahan, rumah penginapan dan sejenis;

2. Pajak Restoran adalah pajak atas pelayanan yang disediakan oleh fasilitas penyedia makanan dan/atau minuman dengan dipungut bayaran, yang mencakup juga rumah makan, kafetaria, kantin, warung, bar, dan sejenisnya termasuk jasa boga/katering;

3. Target penerimaan pajak adalah besaran penerimaan pajak yang diperkirakan dan ditargetkan untuk diterima sampai akhir tahun.

4. Realisasi penerimaan pajak adalah jumlah penerimaan pajak yang diterima sampai tanggal 17 Juni 2020.

\section{IV.HASIL DAN PEMBAHASAN}

\subsection{Hasil Penelitian}

1. Dampak Covid-19 terhadap target pajak hotel dan restoran Kota Makassar

Covid-19 terjadi pada awal tahun 2020 yang menyebabkan terjadinya pembatasan sosial (social distancing), pembatasan jarak fisik (phisical distancing) bahkan pembatasan sosial berskala besar (PSBB). Pembatasan tersebut mulai terjadi secara bertahap pada bulan Maret 2020 dan berlangsung sampai sekarang. Pembatasan tersebut menyebabkan terjadinya penurunan aktivitas ekonomi seperti menurunnya pengguna hotel yang menyebabkan penurunan pajak hotel dan penurunan konsumen restoran yang menyebabkan penurunan pajak restoran. Hal ini dapat menyebabkan menurunnya target pajak dan realisasi pajak.

Sehubungan dengan itu, maka dampak dari covid -19 terhadap target pajak dapat dilihat data target penerimaan pajak sebelum terjadi covid-19 yakni tahun 2019 dengan setelah terjadinya covid-19 yakni tahun 2020 yakni dalam penelitian ini sampai tanggal 17 Juni 2020.

\section{Tabel 1}

Perbandingan target penerimaan pajak hotel dan restoran tahun 2019 dengan tahun 2020

\begin{tabular}{crrrrr}
\hline \multirow{2}{*}{ No } & \multirow{2}{*}{ Jenis pajak } & \multicolumn{2}{c}{ Target } & \multicolumn{1}{c}{ Selisih } \\
\cline { 2 - 6 } & \multicolumn{1}{c}{ Tahun 2019 } & \multicolumn{1}{c}{ Tahun 2020 } & \multicolumn{1}{c}{ Jumlah } & $\%$ \\
\hline 1 & Pajak hotel & 135.000 .000 .000 & 72.000 .000 .000 & -63.000 .000 .000 & -47 \\
2 & Pajak restoran & 185.000 .000 .000 & 104.637 .986 .374 & -80.362 .013 .626 & -43 \\
Total & 320.000 .000 .000 & 176.637 .986 .374 & -143.362 .013 .626 & -45
\end{tabular}

Sumber: Badan Pendapatan Daerah Kota Makassar tahun 2020 (diolah)

Dari tabel di atas menunjukkan bahwa total target penerimaan pajak hotel dan restoran Kota Makassar 2020 sebesar Rp 176.637.986.374 dan tahun 2019 sebesar Rp 320.000.000.000 berarti terjadi penurunan sebesar Rp 143.362.013.626 (45\%). Kedua jenis pajak tersebut mengalami penurunan yakni pajak hotel $47 \%$ dan pajak restoran $43 \%$. Jadi dampak covid-19 terhadap target 
penerimaan pajak hotel dan restoran Kota Makassar adalah menyebabkan terjadinya penurunan target pajak tahun 2020 sebesar $45 \%$ dari tahun sebelumnya.

\section{Dampak Covid-19 terhadap Realisasi Pajak hotel dan restoran Kota Makassar}

Dampak covid-19 terhadap realisasi penerimaan pajak hotel dan restoran Kota Makassar dapat dilihat dari data perbandingan realisasi penerimaan pajak hotel dan restoran Kota Makassar sebelum dan sesudah covid -19. Data penerimaan pajak hotel dan restoran tahun 2020 baru sampai 17 Juni 2020 sehingga yang dibandingkan adalah data realisasi penerimaan pajak hotel dan restoran sampai 17 Juni 2019 dengan sampai 17 Juni 2020. Adapun hasil pengolahan data perbandingan realisasi penerimaan pajak hotel dan restoran tersebut sebagaimana pada tabel berikut ini.

Tabel 2

Perbandingan realisasi penerimaan pajak hotel dan restoran sampai 17 Juni 2020

\begin{tabular}{llllcl}
\hline \multirow{2}{*}{ No } & \multirow{2}{*}{ Jenis pajak } & \multicolumn{2}{c}{ Realisasi } & \multicolumn{2}{c}{ Selisih } \\
\cline { 3 - 6 } & & \multicolumn{1}{c}{ Tahun 2019 } & Tahun 2020 & Jumlah & $\%$ \\
\hline 1 & Pajak hotel & 41.129 .798 .882 & 28.704 .764 .720 & -12.425 .034 .162 & -30 \\
2 & Pajak restoran & 93.172 .323 .257 & 65.919 .941 .260 & -27.252 .381 .997 & -29 \\
& Total & 134.302 .122 .139 & 94.624 .705 .980 & -39.677 .416 .159 & -30 \\
\hline
\end{tabular}

Sumber: Badan Pendapatan Daerah Kota Makassar tahun 2020 (diolah)

Dari tabel di atas menunjukkan bahwa total realisasi penerimaan pajak hotel dan restoran Kota Makassar sampai 17 Juni 2020 sebesar Rp 94.624.705.980 dan tahun 2019 sebesar Rp 134.302.122.139 berarti terjadi penurunan penerimaan pajak hotel dan restoran sebesar Rp 39.677.416.159 (30\%). Kedua jenis pajak tersebut mengalami penurunan realisasi yakni pajak hotel $30 \%$ dan pajak restoran $29 \%$.

\subsection{Pembahasan}

1. Dampak Covid-19 terhadap Target Pajak hotel dan restoran Kota Makassar

Hasil penelitian ini menunjukkan bahwa terjadi penurunan target penerimaan pajak hotel dan restoran Kota Makassar pada tahun 2020. Terjadinya penurunan target tersebut karena pemerintah Kota Makassar sudah memprediksi terjadinya penurunan realisasi penerimaan pajak akibat adanya covid-19. Covid-19 terjadi pada awal tahun 2020 yang menyebabkan terjadinya pembatasan sosial (social distancing), pembatasan jarak fisik (phisical distancing) bahkan pembatasan sosial berskala besar (PSBB). Pembatasan tersebut mulai terjadi secara bertahap pada bulan Maret 2020 dan berlangsung sampai sekarang. Pembatasan tersebut menyebabkan terjadinya penurunan aktivitas ekonomi. Hal ini menyebabkan perkiraan terjadinya penurunan total pajak hotel dan restoran Kota Makassar. Menurut penulis, dampak covid-19 terhadap target (perkiraan penerimaan) pajak hotel dan restoran adalah menurunkan pajak hotel dan pajak restoran.

Adapun jastifikasi penulis terhadap target setiap jenis pajak adalah:

a. Target penerimaan Pajak hotel menurun, menurut penulis adalah benar karena berkurangnya orang yang menggunakan jasa penginapan dan jasa lainnya di hotel. Terjadi penurunan drastis orang yang menginap di hotel, bahkan tidak ada lagi kegiatan pelatihan, seminar dan pesta 
perkawinan di Hotel. Hal ini menyebabkan penurunan pendapatan hotel sehingga pajaknya juga pasti turun sehingga target penerimaan pajak hotel turun.

b. Target penerimaan Pajak restoran menurun, menurut penulis adalah benar karena berkurangnya orang yang menggunakan jasa restoran. Selama covid banyak orang takut makan di restoran, di rumah saja makan. Hal ini menyebabkan penurunan pendapatan restoran sehingga pajaknya juga pasti turun sehingga target penerimaan pajak restoran turun.

Hasil penelitian ini menunjukkan bahwa dampak covid-19 berpengaruh negatif terhadap total target pajak hotel dan restoran kota Makassar tahun 2020 yakni menyebabkan penurunan target pajak tahun 2020. Hasil penelitian ini mendukung pernyataan dalam Hanoatubun, S. (2020), Susilawati, Falefi dan Purwoko (2020) dan Santoso, Y. I. (2020). Ibrahim, A., A. (2020) dan Utomo, S. (2020) yang pada intinya menyatakan bahwa dampak covid-19 terhadap perekonomian adalah terjadinya banyak PHK, Kontraksi PMI Manufacturing, banyak penerbangan dibatalkan, kunjungan turis turun dan penurunan occupansi hotel. Hal ini tentunya menurunkan nilai objek pajak hotel dan restoran sehingga target atau perkiraan penerimaan pajak menurun. Hasil penelitian ini juga mendukung pula pernyataan Direktur Jenderal Pajak Kristiadi, B. B. (2020) yang menunjukkan bahwa covid-19 berpengaruh negatif terhadap berbagai sektor ekonomi menyebabkan penurunan objek pajak sehingga diperkirakan terjadi penurunan penerimaan. Hasil penelitian ini mendukung pula hasil penelitian Silpa Hanoatubun (2020), Burhanuddin, C. I. dan Ardi (2020), Susilawati, Falefi dan Purwoko (2020), Pitaloka, dkk. (2020) dan Feyisa, H. L. (2020) yang menunjukkan bahwa covid-19 berpengaruh negatif terhadap perekonomian Indonesia. Penurunan aktivitas tersebut menyebabkan penurunan objek pajak sehingga diperkirakan terjadi penurunan penerimaan pajak hotel dan restoran Kota Makassar.

2. Dampak Covid-19 terhadap Realisasi Pajak hotel dan restoran Kota Makassar

Hasil penelitian ini menunjukkan bahwa terjadi penurunan total realisasi penerimaan pajak hotel dan restoran Kota Makassar pada tahun 2020. Menurut jastifikasi penulis adalah benar. Terjadinya penurunan tersebut akibat adanya covid-19. Covid-19 terjadi pada awal tahun 2020 yang menyebabkan terjadinya pembatasan sosial (social distancing), pembatasan jarak fisik (phisical distancing) bahkan pembatasan sosial berskala besar (PSBB). Pembatasan tersebut mulai terjadi secara bertahap pada bulan Maret 2020 dan berlangsung sampai sekarang. Jadi penurunan tersebut terjadi mulai bulan Maret 2020.

Adapun jastifikasi penulis terhadap realisasi setiap jenis pajak adalah:

a. Realisasi penerimaan Pajak hotel menurun. Menurut penulis penurunan tersebut akibat dampak negatif dari covid-19. Covid-19 menyebabkan berkurangnya orang yang menggunakan jasa penginapan dan jasa lainnya di hotel. Terjadi penurunan drastis orang yang menginap di hotel, bahkan tidak ada lagi kegiatan pelatihan, seminar dan pesta perkawinan di Hotel. Hal ini menyebabkan penurunan pendapatan hotel sehingga pajaknya juga pasti turun sehingga realisasi penerimaan pajak hotel turun.

b. Realisasi penerimaan Pajak restoran menurun. Menurut penulis penurunan tersebut akibat dampak negatif dari covid-19. Covid-19 menyebabkan berkurangnya orang yang menggunakan jasa restoran. Selama covid banyak orang takut makan di restoran, di rumah saja makan. Hal ini menyebabkan penurunan pendapatan restoran sehingga pajaknya juga pasti turun sehingga realisasi penerimaan pajak restoran turun.

Hasil penelitian ini menunjukkan bahwa dampak covid-19 berpengaruh negatif terhadap total realisasi pajak hotel dan restoran kota Makassar tahun 2020 yakni menyebabkan penurunan realisasi pajak tahun 2020. Hasil penelitian ini mendukung pernyataan dalam Hanoatubun, S. (2020), Susilawati, Falefi dan Purwoko (2020) dan Santoso, Y. I. (2020). Ibrahim, A., A. (2020) 
dan Utomo, S. (2020) yang pada intinya menyatakan bahwa dampak covid-19 terhadap perekonomian adalah terjadinya banyak PHK, Kontraksi PMI Manufacturing, banyak penerbangan dibatalkan, kunjungan turis turun dan penurunan occupansi hotel. Hal ini tentunya menurunkan nilai objek pajak hotel dan restoran sehingga realisasi atau perkiraan penerimaan pajak menurun. Hasil penelitian ini juga mendukung pula pernyataan Direktur Jenderal Pajak Kristiadi, B. B. (2020) yang menunjukkan bahwa covid-19 berpengaruh negatif terhadap berbagai sektor ekonomi menyebabkan penurunan objek pajak sehingga diperkirakan terjadi penurunan penerimaan. Hasil penelitian ini mendukung pula hasil penelitian Silpa Hanoatubun (2020), Burhanuddin, C. I. dan Ardi (2020), Susilawati, Falefi dan Purwoko (2020), Pitaloka, dkk. (2020) dan Feyisa, H. L. (2020) yang menunjukkan bahwa covid-19 berpengaruh negatif terhadap perekonomian Indonesia. Penurunan aktivitas tersebut menyebabkan penurunan objek pajak sehingga terjadi penurunan realisasi penerimaan pajak hotel dan restoran Kota Makassar pada tahun 2020.

\section{KESIMPULAN}

Adapun kesimpulan pada penelitian ini sebagai berikut:

1. Dampak covid-19 terhadap target pajak hotel dan restoran Kota Makassar adalah berdampak negatif yakni menurunkan target penerimaan pajak hotel dan restoran Kota Makassar.

2. Dampak covid-19 terhadap realisasi pajak hotel dan restoran Kota Makassar adalah berdampak negatif yakni menurunkan realisasi penerimaan pajak hotel dan restoran Kota Makassar.

\section{UCAPAN TERIMA KASIH}

Penulis mengucapkan banyak terima kasih kepada Kepala BAPENDA Kota Makassar beserta staf yang telah membantu memberikan data dan informasi yang berkaitan dengan pajak daerah Kota Makassar.

\section{DAFTAR PUSTAKA}

Agustiyanti. (2020). Penerimaan pajak terancam meleset jauh dari target akibat corona. di Katadata.co.id. Diakses, 19 Juli 2020

Burhanuddin, C. I. \& Ardi. (2020). Ancaman krisis ekonomi global dari dampak penyebaran virus corona (Covid-19). Jurnal AkMen, Volume 17 Nomor 1 Maret 2020

Connolly, S., \& Alistair, M. (1999). Economics of the public sector, Prentice Hall, New York

CSIS Indonesia. (2020). Mengukur dampak covid-19 pada pertumbuhan ekonomi dan perdagangan indonesia 2020. Jakarta.

Depdagri, Kepmendagri No. 690.900.327 tahun 1996 tentang Pedoman Penilaian dan Kinerja Keuangan

Devas, N., et al. (1999). Keuangan pemerintah daerah di indonesia: UI Press, Jakarta.

Feyisa, H. L. (2020). The world economy at covid-19 quarantine: contemporary review. International journal of economics, finance and management sciences, 8, 63-74

Hanoatubunn, S. (2020). Dampak covid-19 terhadap perekonomian Indonesia. EduPsiCount Journal, 2 (2)

Ibrahim, A.A. (2020). Dampak dari pandemi covid terhadap perekonomian indonesia dan kebijakan pemerintah indonesia. balewarga. Diakses 20 Juli 2020.

Iwan, T.A. (2009). Analisis pajak hotel dan restoran kabupaten klaten periode 2004-2008. Tesis, PPS, Universitas Muhammadiyah, Surakarta. 
Kristiadi, B. B. (2020). Pandemi covid-19 akan menentukan masa depan sektor perpajakan. Kontan.co.id. Diakses 19 Juli 2020

Mayasari, D. (2006). Kontribusi penerimaan pajak hotel dan restoran terhadap pendapatan asli daerah (Analisis terhadap kabupaten dan kota di Jawa Timur). Tesis, PPS, Universitas Muhammadiyah, Malang

Peraturan daerah kota makassar nomor 2 tahun 2018 tentang pajak daerah

Priangga, M. (2009). Pengertian dasar dan ciri-ciri pajak - definisi pajak. http://maksumpriangga.com/pengertian-dasar-dan-ciri-ciri-pajak-definisi-pajak.html. Diakses, 5 Mei 2011.

Republika.co.id. (2020). Harga sarang burung walet merosot akibat wabah corona. Kamis 06 Feb 2020. Https://republika.co.id/berita/q59w1r463/harga-sarang-burung-walet-merosotakibat-wabah-corona. Diakses, 16 Juli 2020

Santoso, Y. I. (2020). Ini delapan dampak negatif bagi perekonomian indonesia akibat virus corona. Retrieved May 13, 2020, from Kontan.co.id website: https://kontan.co.id/news/ini-delapandampak-negatif-bagi-perekonomian-indoneisa-akibat-wabah-virus-corona

Sodang, S.P. dalam buku. Jhingan, ML.1994. Ekonomi pembangunan dan perencanaan, Edisi Pertama, Cetakan Kelima, PT. Grafindo Periode January.

Surabaya Net. (2020). Dampak covid19 terhadap ekonomi global. Retrieved April 18, 2020, from https://www.suarasurabaya.net/ekonomibisnis/2020/dampak-covid-19-terhadap-ekonomiglobal-2020/?amp

Susilawati, F., \& Purwoko. (2020). Impact of covid-19's pandemic on the economy of indonesia. Budapest International Research and Critics Institute-Journal (BIRCI-Journal). 3 (2).

Pitaloka, dkk. (2020). The economic impact of the Covid-19 outbreak: Evidence from Indonesia. Jurnal Inovasi Ekonomi. 2(2).

UU RI Nomor 32 Tahun 2004 tentang pemerintah daerah

UU RI Nomor 33 Tahun 2004 tentang perimbangan keuangan antara pemerintah pusat dan daerah.

UU RI Nomor 28 Tahun 2009 tentang pajak daerah dan retribusi daerah

Utomo, S. (2020). Bos ditjen pajak ungkap 3 dampak corona terhadap ekonomi. CNN Indonesia Selasa, 14/07/2020. Diakses 19 Juli 2020

Wisanggeni, I. (2020). Mengkaji insentif pajak atas covid-19. Kontan.co.id. Diakses 19 Juli 2020 